\title{
Bi-musical Curricula and "Abyssal Thinking": The Case of KM Music Conservatory, India
}

\author{
Rupert Avis \\ University of York, UK
}

This article explores student and teacher experiences of bi-musical education at $\mathrm{KM} \mathrm{Mu-}$ sic Conservatory (KM). KM is a higher education institution in Chennai, India, established in 2008 by the internationally renowned film composer, $A$. R. Rahman. The Conservatory offers various courses, including a Diploma programme validated by Middlesex University, UK, as part of an internationally recognised bachelor's degree in music. Students enrolled in the diploma programme study Western art music and Hindustani classical music as core subjects alongside audio engineering, in what has been described as a bi-musical curriculum. Teacher and student experiences of KM's curriculum indicate bi-musical education can reaffirm colonial, Orientalist, and neoliberal discourses. I argue this should be recognised as an outcome of bi-musical education; however, I also argue that if the generation of these discourses is acknowledged, bi-musical education can bring into dialogue a diverse range of issues that can be used to confront and unsettle colonial ideology, Orientalism, and neoliberalism in engaged ways.

Keywords: Western art music, Hindustani classical music, India, bi-musicality, Orientalism, colonialism, neoliberalism, abyssal thinking

$\mathrm{I}$ ndia's musical history is defined by musical encounters and syncretic practices that have been shaped by musical, socioeconomic, political, and technological factors. Music therefore brings into dialogue a diverse range of issues and is a particularly rich site to explore important musical and social concerns. KM Music Conservatory (KM) ${ }^{1}$ is a higher education institution established in 2008 by the internationally renowned film composer A. R. Rahman and located in Chennai, South India. ${ }^{2}$ It is marketed as "[meeting] the highest standards of international education, attracting faculty and students from around the world."3 The Conservatory offers various courses, amongst which is a diploma programme validated by Middlesex University, UK, as part of an internationally recognised bachelor's degree in music. Students enrolled in the diploma programme study Western art music and Hindustani classical music as core subjects 4 alongside audio engineering,

(C) Rupert Avis. The content of this article is the sole responsibility of the author. The ACT Journal and the Mayday Group are not liable for any legal actions that may arise involving the article's content, including, but not limited to, copyright infringement. 
in what has been described as a bi-musical curriculum (Taylor 2015). The Conservatory successfully attracts a steady stream of students as a result of various factors, including Rahman's iconic reputation which has elevated the social status of the music profession and music education in contemporary India; the formative influence of Western art music, Hindustani classical music, and audio engineering on Indian film music; changing job markets resulting from the oversaturation of professions such as engineering; and an expanding affluent middle class with a disposable income and global orientation (see Derné, Sharma, and Sethi 2014, Fernandes 2006, Brosius 2010) who are willing and able to pay fees upwards of c. INR 6 Lakh (c. \$800o) for an internationally recognised music education (see Avis 2017).5

The coexistence of Western art music and Hindustani classical music in KM's curriculum along with the socioeconomic, political, and historical contexts that surround it raises questions about how these traditions are experienced and represented in this educative space. Tuck and Yang (2012) have warned that educational endeavours may affirm and perpetuate colonisation by failing to unveil and dismantle the origin and terms of colonial oppression. They argue plural and diverse educational curricula do not necessarily have outcomes that align with decolonisation and can function as "moves to innocence" to "relieve settler guilt" $(2012,10)$, i.e., incorporating indigenous knowledge within curricula does not constitute decolonisation, which Tuck and Yang define as the repatriation of land from settlers to indigenous communities. Linked to this, it has been argued that multicultural educational projects perpetuate colonial ideologies leading to the "Othering" (invalidation and essentialising) of "non-Western" epistemologies when they are framed by Western notions of modernity, progress, globalisation and international development (see Mignolo 2011, Quijano 2000). Boaventura de Sousa Santos has written extensively on the epistemological hegemony of the West, describing the invalidation of non-Western knowledge brought about through the perpetuation of the hegemonic positioning of modern science, and the failure to "acknowledge as valid kinds of knowledge other than those produced by modern science" $(2018,8)$. This is what Santos describes as "abyssal thinking" or the "abyssal line"-the line dividing metropolitan from colonial societies (or valid from invalid epistemologies) - that he argues has been perpetuated decades after the end of historical colonialism. Not only is this indicative of external influences but, as Santos argues, of inner colonialism-a recolonization from within-resulting in the privileging of Western epistemology outside the "West."

Avis, Rupert. 2019. Bi-musical curricula and "abyssal thinking": The case of KM Music Conservatory, India. Action, Criticism, and Theory for Music Education 18 (3): 26-55. https://doi.org/ 10.22176/act18.3.26 
Particularly useful are what Santos (2012) identifies as the "five logics" of Western epistemology. The first logic is what he describes as the "'monoculture of knowledge' or 'rigour of knowledge' [that] consists in turning modern science and high culture into the sole criteria of truth and aesthetic quality" $(2012,52)$. The second logic is the "'monoculture of linear time', the idea that history has a unique and well-known meaning and direction" (52). The third logic is "the logic of social classification, based on the monoculture of 'naturalisation of differences.' It consists in distributing populations according to categories that naturalise hierarchies" (53). The fourth logic is the "logic of the dominant scale" that in relation to Western modernity appears in two forms: the universal and the global (54). Finally, the fifth logic is the "'logic of productivity.' It resides in the monoculture of the criteria of capitalist productivity. According to this logic, economic growth is an unquestionable rational objective" (54-5). Santos argues that the five logics serve to produce epistemological absences or non-existence that are labelled "ignorant, backward, inferior, local or particular, and unproductive or sterile" (2012, 52). Santos argues that these "absences" are often applied to epistemologies deemed to lie outside the West, capitalism, modern science, and high culture.

Against such dichotomised understandings, Santos calls for "an ecology of knowledges [in which] postabyssal thinking is premised upon the idea of the epistemological diversity of the world, the recognition of the existence of a plurality of knowledges beyond scientific knowledge" (2007, 67). More recently he has described this as a "pluriversality" rather than an "abstract universality" $(2018,7)$, arguing against the "dualistic, binary structure of Western imagination." For Santos (2012), it is recognition of the perpetuation of abyssal thinking and dualism that is vital in redressing the hegemonic relations between the global North and South (6). A key concept in challenging abyssal thinking is the concept "intercultural translation" that allows for "mutual intelligibility among the experiences of the world [that] does not endow any set of experiences with the statute [sic.] (status) either of exclusive totality or homogenous part" (56). Linked to this, he argues "the epistemologies of the south are not the symmetrical opposite of the epistemologies of the north, in the sense of opposing one single valid knowledge against another one" (10).

Taking inspiration from Santos' work, I show that KM and its bi-musical curriculum can serve to perpetuate abyssal thinking and privilege "Northern" epistemologies in the ways Santos identifies. First, I position KM within the wider context of music education institutions in India, exploring the influence of colonial tory, India. Action, Criticism, and Theory for Music Education 18 (3): 26-55. https://doi.org/ 10.22176/act18.3.26 
legacies, neoliberalism, and internationalism. I then contextualise historical encounters between Western art music and Indian classical music, signposting and complicating the influences of colonial, Orientalist, and neoliberal discourses. Finally, I show the ways in which teacher and student experiences of KM's bi-musical curriculum can reaffirm colonial, neoliberal and Orientalist discourses. Although bi-musical education is inherently problematic, I argue that it brings into dialogue a wide variety of issues that, if recognised, compel us to confront and unsettle colonialism, neoliberalism, and Orientalism in engaged and meaningful ways. ${ }^{6}$

\section{Positionality}

It bears mention that I am a white, middle-class, male researcher and Western classically trained musician who has been educated to the doctoral level in the UK. I have a rudimentary understanding of the Indian classical traditions, although I am currently learning sarangi and gayan (Hindustani classical vocals). I have spent a significant amount of time in India since 2007, teaching Western art music at various institutions, giving me detailed insight into the significance of this music in contemporary, metropolitan India (this is the subject of my doctoral thesis).

\section{Methodology}

Semi-structured interviews were conducted with students and teachers over a four-month period at KM Music conservatory in 2015. Interviews ranged from 45 minutes to 1.5 hours and focused on teacher and student experiences of pedagogy, performance, student-teacher relationships, the perceived value of education, and representations of Western art music and Hindustani classical music. I also drew upon field notes generated through participant observation as a teacher, performer, and observer in seminars, lectures, workshops, and performances. All participants have been anonymised-Christian pseudonyms have been used for those with Christian names and Hindu pseudonyms for those with Hindu names. Ethical approval for this research was granted by the Arts and Humanities Ethics Committee, University of York, UK.

Avis, Rupert. 2019. Bi-musical curricula and "abyssal thinking": The case of KM Music Conservatory, India. Action, Criticism, and Theory for Music Education 18 (3): 26-55. https://doi.org/ 10.22176/act18.3.26 


\section{KM Music Conservatory and Music Education in India}

$\mathrm{KM}$ is a recent instantiation in a long history of music institutions in Chennai. Towards the end of the nineteenth century, music retailers were established in major cities to cater for European and non-European community interest in Western art music. These retailers engaged in an international trade for upright pianos, organs, gramophone recordings, radios, and sheet music, and often provided music education. In 1842, Misquith and Co. (now Musée Musical) was established in Chennai to cater for the city's European and Anglo-Indian communities, to repair organs and pianos, and, since 1906, has served as a music school and centre for Trinity College of Music examinations-a UK-based exam board-in South India. In addition to KM, a number of institutions have been established in Chennai in recent years, including Pavo School of Music (2006) and the Academy of Western Music (2012). These latter institutions share the same aims, objectives, and markets as Musée Musical: they teach Western art music and popular music through international examination boards, primarily Trinity College of Music but also the Associated Board of the Royal Schools of Music (ABRSM), and London College of Music (LCM)-and cater to a client-base made up largely of affluent, middle-class Indians.

This shows that music institutions have been adapted to and shaped by local economic contexts, changing markets and consumer tastes. For example, Musée Musical has transitioned from catering predominantly to Europeans ${ }^{7}$ and AngloIndians ${ }^{8}$ during the late nineteenth and early twentieth centuries to catering for an almost exclusively Indian market, adapting the education it offers to accommodate complex and shifting musicscapes and consumer tastes. As well as selling Western instruments such as pianos, violins, and guitars, Musée Musical also stocks veenas, sitars, and harmoniums. In addition to Western art music tuition, Musée Musical also teaches Hindustani and Carnatic classical music as well as Western popular music through Trinity's Rock and Pop syllabus. As a marketing strategy, Musée Musical draws on the popularity of Indian film music, listing A. R. Rahman as one of their former pupils and citing the formative influence of Western art music on Indian film music. ${ }^{9} \mathrm{KM}$ and its bi-musical curriculum are not an anomaly but part of a long tradition of music education in Chennai that is perpetually adapted to changing consumer tastes and markets, and encompasses interest in Western art music, Indian classical music, Indian film music, as well as popular music.

Avis, Rupert. 2019. Bi-musical curricula and "abyssal thinking": The case of KM Music Conservatory, India. Action, Criticism, and Theory for Music Education 18 (3): 26-55. https://doi.org/ 10.22176/act18.3.26 
Such educational contexts are also symptomatic of the interconnectedness of the global market place. Historically, Trinity College of Music has dominated the market for Western music education in India, establishing examination centres during the early twentieth century. ${ }^{10}$ A surge in interest in ABRSM examinations in recent years has challenged Trinity's position, as has interest in Rock School and LCM examinations. Again, the accreditation of KM by Middlesex University is part of a long history of international interest in India, and one that seems to be expanding-Berklee College of Music (US) and the Royal Scottish Conservatoire of Music and Drama (UK) have shown interest in forging links with Indian institutions. As Taylor notes, "Western universities are falling over themselves to establish formal links with institutions in emerging nations, in order to fulfil the corporate agenda of the former and the capacity and accreditation challenges of the latter" (Taylor 2016, 88). Thus, Middlesex University gains lucrative international fees from students, KM gains international recognition, and students have the opportunity to attain an internationally recognised degree.

Such overt internationalism brings ideological baggage with it. Cambridge and Thompson comment that "international education has been used to denote an ideology of education oriented towards 'internationalism' and 'international-mindedness"' (2004, 161). Similarly, according to Lowe (1998), "internationalism seeks to develop international attitudes and awareness" (18-19). For Taylor, such internationalism is replete with contradiction and ambiguity. "What appears on the surface as an egalitarian ideology often serves as a mechanism for maintaining unequal power relations between the West and the rest: thinking and acting globally relies on wielding the economic power to impose your ideas onto others" (Taylor 2016, 88). Indeed, KM can be seen as symptomatic of what Sivadasan (2015) has identified as a neoliberal turn in Indian higher education policies that is inherently tied to economic liberalisation, free markets, and private enterprise. As in other postcolonial ${ }^{11}$ countries (see Mignolo 2007), India suffered financial crises in the 1980 s that led to economic liberalisation in the early 1990s-an "openingup" of the economy to foreign investment, free market capitalism, and a serviceoriented economy. ${ }^{12}$ In 1994, India signed the World Trade Organisation Act, which supported the privatisation of education, culminating in the Private Universities Act in 1995 and subsequent emergence of privately funded higher education institutions. For Goswami (2013), such neoliberal paradigms have displaced egalitarian commitments to education propagated prior to economic liberalisation and have embraced educational goals based on the pursuit of profit and the preparation

Avis, Rupert. 2019. Bi-musical curricula and "abyssal thinking": The case of KM Music Conservatory, India. Action, Criticism, and Theory for Music Education 18 (3): 26-55. https://doi.org/ 10.22176/act18.3.26 
of a cheap and compliant workforce. Moreover, the "opening-up" of the Indian economy to global markets has facilitated the import of goods (including musical instruments by companies such as Yamaha), as well as greater scope for international organisations to tap into the Indian market. In all of India's major cities, a plethora of Western-style music institutions have been established and, as elsewhere (see Baker 2014, 2016 and Rosabal-Coto 2016), propagate discourses associated with neoliberalism and internationalism.

In relation to the broader context of education, Amanda Gilbertson (2014) has noted the proliferation of international schools that are only accessible to wealthy upper-middle class families. Gilbertson suggests these schools are popular due to the perception that they develop communication skills, "open-mindedness," and provide exposure to global cultural trends deemed to have value in global job markets. Two things are worth noting here: first, the fees charged by KM restrict its education to only the very wealthy; and second, the socioeconomic shifts that have accompanied economic liberalisation have led to changes in the aspirations and values of India's middle-classes, including an embrace of "liberal values," cosmopolitanism, metropolitanism, and global cultural trends (Brosius 2010, 2; BeasterJones 2016, 9; also see Joshi 2017 for a brief history of the Indian middle class). For Brosius (2010), this "new" middle class is "a large and heterogeneous middle class that is distinctly different from the 'old' middle class [of the post-independence era]," (2) who held a more communal, left-leaning and nationally-oriented ideology (also see Joshi 2017). ${ }^{13}$ As I will explain, music education-especially Western art music-is often mobilised as a signifier of "liberal" values, cosmopolitanism, metropolitanism, and "modernity" for India's middle-classes.

\section{A History of Musical Encounters}

Encounters between Indian and Western music also provide significant insights into the discourses and representations that surround these musical traditions. Rabindranath Tagore, the renowned Bengali writer, provides an illustrative example of these issues. Describing his experiences of European and Indian music in the early twentieth century, Tagore writes:

To my mind, the daytime world is like European music-consonant and dissonant bits and pieces are combined to produce an overall harmony. And the night-time world is like our Indian music-a pure, poignant, solemn, unmixed raga. We are stirred and moved by both, yet they are opposed to each other. ... Our melodies

Avis, Rupert. 2019. Bi-musical curricula and "abyssal thinking": The case of KM Music Conservatory, India. Action, Criticism, and Theory for Music Education 18 (3): 26-55. https://doi.org/ 10.22176/act18.3.26 
are lonely and single; Europe's music is social and communal (in Radice 2005, 48).

Tagore's comments fit with archetypal conceptions of the differences perceived to exist between Indian and Western music: lack of harmony in Indian classical music, the association of large-scale ensembles with Western art music, the meditative, solitary, and spiritual nature of Indian classical music contrasted with the social and material world of Western traditions, and one could add the association of Indian classical music with aural transmission and Western art music with text and notation. Whilst the bifurcation of these traditions is reductive, Orientalist representations abound in the history of encounters between Western and Indian music. During the nineteenth and twentieth centuries, Indian classical music was sometimes described as wild, feminine, and barbarous and compared unfavourably with Western art music, which was considered controlled, masculine, and rational. ${ }^{14}$ These discourses are reflected in the crystallisation of practices that became associated with Western art music during the nineteenth century, including concert culture, the prevalence of the musical score and a strong work-concept, institutionalised and "systematic" music pedagogy, and the mobilisation of universalising narratives to articulate its meaning. Whilst these practices and discourses have been destabilised in musicological literature (see Nooshin 2011), they still characterise $^{15}$ much of the dissemination of Western art music around the world (Taylor 2016). Moreover, such discourses resonated with the increasing prevalence (although often nuanced and far from universal) of derogatory attitudes towards Indian culture as European powers (especially the British) consolidated their position in India during the nineteenth century. This is exemplified in Thomas Babington Macaulay's' ${ }^{16}$ (1835)17 infamous "Minute on Indian Education," in which he described the need to supplant Indian pedagogic methods with those of the West in an attempt to control, civilise, and modernise the Indian populace (see Seth 2007).

Western art music's and Hindustani classical music's position, however, within a bi-musical curriculum is far more complicated-a simple bifurcation of these musical traditions ignores their entangled histories. The values and ideas associated with Western musical forms became embedded, ${ }^{18}$ at least to some extent, in the musical practices and ideologies of Indian classical music in the nineteenth century. ${ }^{19}$ Attempts to define Indian classical music in relation to Western art music became a driving force for modernisers who sought to elevate its status to that

Avis, Rupert. 2019. Bi-musical curricula and "abyssal thinking": The case of KM Music Conservatory, India. Action, Criticism, and Theory for Music Education 18 (3): 26-55. https://doi.org/ 10.22176/act18.3.26 
of the Western tradition and to distinguish it from folk musics. This led to the adoption of Western-influenced ideas of the autonomous musical work and formal concert performance, ${ }^{20}$ staff notation, and the establishment of Indian classical music institutions (see Weidman 2006, Bakhle 2005, Subramanian 2006, van der Linden 2013). ${ }^{21}$ Indeed, Subramanian (2006) has suggested Orientalist thought influenced modernisers of Carnatic classical music, who drew on a self-Orientalising discourse that elevated and fixated on the spiritual and transcendental "nature" of the Indian classical traditions. ${ }^{22}$ Similarly, van der Linden (2013) has argued that the modernisation of the Indian classical traditions played into colonial ideology through the adoption of discourses of essentialised difference between East and West, to distinguish it from Western art music. ${ }^{23}$ Orientalist representations of the Indian classical traditions are still prevalent today and are problematic. Indeed, the ways both Western art music and Hindustani classical music are represented has the potential to generate dualisms that flatten the diversity inherent within them.

Linked to this, Martin Clayton and Bennet Zon (2007) have argued for "continued ideological critique of musical Orientalism and for renewed emphasis on encounter and mutual influence of East and West" (1). Clayton (2007) has outlined the influence of nationalist and evolutionist ideologies in the musical worlds of both coloniser and colonised through:

imitation, appropriation and rhetorical distancing-and of collusion between the two country's elites which had the effects of marginalising those who could not fit easily into the "reborn" music traditions and, paradoxically, of denying that very collusion in favour of an ideology of essential difference (4).

Clayton argues that the music histories of both England and India are denied a crucial dimension through the marginalisation of particular traditions and communities such as hereditary Muslim musicians (also see van der Linden 2013). The history of the classicisation of both traditions can be considered hegemonic, serving to create an abyssal line between what are considered "valid" musical traditions-the classical traditions, and "invalid" musical traditions-popular and folk musics. Such discourses are still propagated today, with both the Western and Indian classical traditions often presented as the most prestigious musical traditions in the world (Potter and Sorrell 2012). ${ }^{24}$

Although colonial and internationalist discourse clearly had an effect on the modernisation of the Indian classical traditions, Schofield (2016) argues that far more significant was the impact of "European notions of the proper uses of space, tory, India. Action, Criticism, and Theory for Music Education 18 (3): 26-55. https://doi.org/ 10.22176/act18.3.26 
time, and resources; ways of doing business; employment of musical labour; interference in older economic modes; civic regulations and jurisprudence; [and] new technologies" (2). Of particular interest for this article are the effects this had on teaching and epistemology. The traditional gharana system-a system of social organisation linking musicians or dancers by lineage or apprenticeship, and by adherence to a particular style-was not considered compatible with the socioeconomic conditions of India's new urban centres, and it was these urban centres and markets that Indian musicians increasingly sought to exploit. Bakhle (2005) shows that these changing contexts created conditions that challenged traditional ways of teaching, such as the ustad and gharana systems (8). For example, Bhatkande, a prominent Hindustani moderniser during the late nineteenth and early twentieth century, was dismissive of what he felt was the secrecy of hereditary Muslim musicians as well as the "unsystematic pedagogy" they used. ${ }^{25}$ Hindustani classical music was subsequently mobilised as emblematic of India's Hindu elites, who imbued it with notions of modernity, "systematic pedagogy" and ontological and epistemological values influenced by Western musical traditions, as well as broader socioeconomic, political, and technological factors. ${ }^{26}$ Various music institutions were established as a result, including the Madras Music Academy in the 1920s. ${ }^{27}$ India's relatively recent embrace of free-market capitalism raises the question of how current socioeconomic conditions shape perceptions of the value of education, especially in relation to educational preference and the adaptation and shaping of epistemology. ${ }^{28}$

The above is further complicated by the persistence of Indian intellectual lineages in Indian pedagogic and musical philosophy. Schofield $(2014,2016)$ has argued against the totalising effect of Western musical practices on the classicisation of Indian music and is dismissive of the notion of a radical break between understandings of Indian music in the Mughal and colonial eras. She challenges the idea that "art music" did not exist in precolonial India, relating the aspects that constitute art music-"veneration, canonisation, standardisation, and systemisation"to the Mughal distinction between margi and desi (high and low music). The perceived dominance of Western epistemology in India should, therefore, be nuanced by the continuing influence of indigenous thought, even if such thought is similarly premised on dualistic foundations. This blurs the dichotomy between West and East; the dualism that Santos associates with Western modernity is, arguably, just as characteristic of the margi-desi distinction. Furthermore, Makarand Paranjape

Avis, Rupert. 2019. Bi-musical curricula and "abyssal thinking": The case of KM Music Conservatory, India. Action, Criticism, and Theory for Music Education 18 (3): 26-55. https://doi.org/ 10.22176/act18.3.26 
(2018) argues that margi and desi are not fixed but contingent and relational concepts that are used to describe distinctions between rural-urban, regional-national, and national-international dichotomies (78-79). The contingent nature of the margi-desi distinction that Paranjape notes is pertinent; Western art music is often associated with urban and international discourses, whilst Indian classical music is often associated with the regional or national. Thus, the potential privileging of epistemologies associated with Western art music could be premised on the margi-desi distinction rather than Western epistemological hegemony. This again blurs the boundaries between East and West and complicates the position of Western art music in KM's bi-musical curriculum.

\section{Negotiating Bi-musical Education}

Abyssal thinking and the five logics and absences Santos highlights can be identified-albeit complicated-in the historical and contemporary context that surrounds KM, Western art music, and Hindustani classical music. This includes issues related to hegemony, Orientalism, self-orientalism, colonialism and neoliberalism. Taylor $(2015,2016)$ has explored the challenges of teaching music history at KM and suggests that promoting understandings of the plural and interconnected musical and social histories of the Western and Indian classical traditions $(2015,125)$ could serve to "dissolve binary oppositions of West and East into a rich historical record of intercultural musical encounters" (2016, 92). Taylor considers the tensions that surround colonial legacies, internationalism, and globalisation. He develops a positive approach to teaching music history at KM that encourages dialogue between students' diverse learning experiences through understandings of the historical and social interconnections between Western and Hindustani classical music, resonating with Santos' "ecologies of knowledges" and "intercultural translation;" however, Taylor glosses over the Orientalist discourses prevalent in the history of musical encounters between these traditions and fundamental to the classicisation of both traditions. Neither does he address the tensions generated by Western notions of critical thinking, goal-oriented education, and their relationship with colonial and neoliberal ideology. He subsequently negates the rich educational experiences that can arise through an acknowledgement of the more problematic outcomes of bi-musical education.

Recent research on bi-musical education has argued for its transformative potential for students, fostering self-reflexive practice that can serve to destabilise

Avis, Rupert. 2019. Bi-musical curricula and "abyssal thinking": The case of KM Music Conservatory, India. Action, Criticism, and Theory for Music Education 18 (3): 26-55. https://doi.org/ 10.22176/act18.3.26 
entrenched attitudes and encourage dialogue between diverse musical knowledges and traditions (see Sorrell 2007; Haddon 2016). For example, Haddon (2016) has explored the experiences of UK students whose primary study is Western art music but who, in addition, study Balinese gamelan. Such exposure, she suggests, can encourage self-reflection on attitudes to performance and learning, encouraging dialogue across epistemologies. Haddon notes benefits including the development of "awareness, flexibility, openness, tolerance, disengagement with the 'ego,' affirmation of others and of the ensemble as a whole, and interest in experimentation." Haddon's work resonates with some of my own experiences and research. For example, the use of meditative techniques and different conceptualisations of performance drawn from exposure to Indian classical traditions that can be used to redefine conceptions of performance that can alleviate performance anxiety amongst Western art musicians. I do not negate the value of bi-musical experiences in encouraging self-reflection on received assumptions and preconceptions; however, it is clear that these benefits are born from narratives that reaffirm Orientalist representations of the "East." For example, Haddon draws on Diamond's (1979) comment that "participation in alternative learning experiences may allow Westerners to rediscover and develop their capacity for intuitive perception" (iii, cited in Haddon 2016, 3). Here, intuition is associated with the non-western world whilst the West, by extrapolation, is represented as unintuitive. Bi-musical experience in this sense results in the (re)creation of distinct and reductive musical worlds and philosophies that plays on well-established Orientalist representations of East and West and essentialised difference.

Deborah Bradley (2012) has provided some insight into how these issues may be negotiated in multimusical educational environments. She argues against what she describes as "epistemological tyranny"-the perpetuation of narratives of universalism and infallibility narratives-and advocates a "fallibilistic epistemology that is comfortable with uncertainty" (693): the acknowledgement that education is never complete and is always problematic. Bradley's position is valuable and serves to problematise curricula that purport to encourage unproblematic plural epistemological understandings whilst simultaneously perpetuating hegemonic discourse. Bradley's argument complements Santos' call for the recognition of "abyssal thinking" in processes of decolonisation, as well as his argument for its acknowledgment in challenging colonial and neoliberal oppression. Rather than positioning music education as an apolitical, innocent, and unproblematic process, it is conceptualised as inherently problematic with its tensions, incompleteness, tory, India. Action, Criticism, and Theory for Music Education 18 (3): 26-55. https://doi.org/ 10.22176/act18.3.26 
and epistemological fallibility laid bare. This is especially pertinent given the socioeconomic, ideological, and historical context that surrounds KM as an institution, as well as the history of musical encounters in India more generally.

\section{Teacher Experiences}

The issues highlighted in the foregoing are illustrated in the experiences of teachers at KM. The Western art music faculty at KM at the time of my research comprised nine members, three of whom came from the UK, three from the US, one from France, one from Indonesia, and one from the Netherlands. All had trained in European or US higher education institutions. At the time of my arrival, George had been working at KM for 4 years-the longest serving international staff member I interviewed. The newest was Lucy, who had recently completed a doctorate in the US and had joined KM as a vocal teacher and lecturer in opera studies. Of the nine members of the Western faculty, I interviewed five: two from the UK and three from the US. The two from the UK had doctorates in musicology from a UK university, and the three from the US had doctorates from US universities. They had all studied for degrees in their home countries with the exception of Johnny, who had studied for a master's degree at a conservatoire in London, and another master's in the Netherlands. The oldest was in his 4Os; the others were in their early-mid 30s. The teachers held differing conceptualisations of Western art music and education, including the goals they hoped to achieve, how Western art music functioned in the context of KM and India more generally, its relationship with Hindustani classical music, as well as their relationship with the Hindustani faculty. I also interviewed Joseph, an ex-faculty member and violinist from the US who had taught in the first year of KM's establishment (2008). I interviewed two Hindustani vocal teachers. Shreya had a doctorate in Hindustani classical music from an Indian university and was a renowned performer, teacher, and scholar of Hindustani music. She had been working at KM since its establishment. Sanjib was from Kerala and had been working at KM for 4 years. Concurrently, he was studying for a $\mathrm{PhD}$ on vocal health at an Indian university, hoping to promote understanding of physiology amongst Indian classical musicians. The two faculties functioned independently; staff from each had relatively little knowledge of the other's traditions, although it should be noted Johnny had rudimentary knowledge of Carnatic classical music, and Sanjib had achieved Grade 5 (ABRSM) in Western classical voice.

Avis, Rupert. 2019. Bi-musical curricula and "abyssal thinking": The case of KM Music Conservatory, India. Action, Criticism, and Theory for Music Education 18 (3): 26-55. https://doi.org/ 10.22176/act18.3.26 
At KM, students typically study for a foundation year (first year), followed by Diploma 1 (second year) and Diploma 2 (third year). The foundation year covers general musical skills, theory, and history, and introduces students to performance and composition. The curriculum for Diploma 1 students is divided into four broad sections: Hindustani classical music, audio engineering, performance and musicianship, and pastiche and history. Western art music constitutes 50\% of the curriculum. Students have the option to focus on either performance or composition in Diploma 2. Although teachers adapt teaching practices to the institutional context of KM and the demands of the curriculum as well as to the diverse musical and learning experiences of students, the ways in which Western art music is taught has many parallels with teaching in UK-based music departments. Students attend lectures on topics such as music theory and history. Lecturers encourage students to engage critically with the content of lectures as well as their musical experiences. Composition tuition ranges from lectures on the development of compositional techniques in areas such as serialism to workshops on free improvisation, sound art, and acoustic and electronic composition. For vocal and instrumental lessons, students predominantly learn through one-to-one tuition. Students have the opportunity to take part in weekly performance classes, which adopt approaches typical of Western art music education in the UK: four to five students out of a class of around twenty take turns to perform and receive feedback from a teacher and fellow students. There are also opportunities for students to join various ensembles, including a chamber choir.

The instrumental and vocal tuition of Hindustani classical music at KM differs from "traditional" practices, and is symptomatic of the ongoing adaptation of Indian education to changing socioeconomic and institutional contexts. Students are not engaged with the gurukal system or guru-shishya relationship, in which students live in a domestic setting with a guru (teacher). George Ruckert (2004) describes the gurukal and guru-shishya approach to education:

In a more or less closed musical society, one's guru was arranged in one's early, formative years, and continued to be a decisive figure throughout a lifetime. A student's connection to the music was through the guru, since there were no other media from which one could learn-and one did not divide one's attention among several gurus. The guru was a dynamic figure, conducting the daily regimen of practice and learning, and regulating all facets of the musical growth of the disciple (shishya) (34).

In contrast, Hindustani teaching at KM typically takes place in a group setting, with around fifteen students attending a lesson. Students sit in a circle and the tory, India. Action, Criticism, and Theory for Music Education 18 (3): 26-55. https://doi.org/ 10.22176/act18.3.26 
teacher demonstrates raags, encouraging students to repeat sections or demonstrate for the rest of the group. In addition to vocal and instrumental tuition, students also attend lectures on the history and theory of Hindustani classical music. Some students are also involved with the Hindustani vocal ensemble, providing a space for ensemble learning-again, not typical of Hindustani classical education or performance-that in some ways mirrors the activities of KM's chamber choir. This locates the tuition of Hindustani classical music at KM in a history of musical encounters and institutional contexts that have encouraged adaptation of the ways in which it is performed and taught (Bakhle 2005, Subramanian, 2006).

The role of the Hindustani teacher at KM can be described as "less involved" than the guru-shishya relationship described by Ruckert. Shreya expressed concerns about the move away from the gurukal and guru-shishya educational practices to a more institutionalised, international curriculum. She stated:

Any education, if it is not grooming a student holistically, then it is not complete because a teacher and education institution shapes a personality; it doesn't just develop skilled people. I am not just concerned with his musical skills, but I am concerned about his overall growth. This is Indian philosophy;... If he is not healthy mentally how will he perform? He needs to gain not only in terms of skills but also spiritually, personality-wise. In the gurukul, they were completely in charge of the students. The gurukul was in charge of the student even if he's not learning, to see he is coming up as a good citizen also. The aim of education should be to create a good human being ... who's positively going to contribute to his family and society.

Shreya's comments portray her dissatisfaction with the institutionalisation and commodification of education that focuses narrowly on skills development, highlighting the tension between the gurukul system and institutionalised education. Her comments resonate with the concerns expressed by Sivadasan (2015) and Goswami (2013) about the effects of neoliberalism and commodification on Indian higher education. It is clear from Shreya's comments that Hindustani teachers are under pressure to adapt teaching practices and philosophies to Western-style institutions and broader socioeconomic contexts in ways that move away from what they consider the traditional, archetypal values of Indian music pedagogy; however, in these comments Shreya also potentially mobilises Orientalist discourses that affirm essentialised difference between Indian and Western pedagogy.

The tension between Western pedagogic styles and the gurukul system raised further questions about epistemology. Many of KM's Western faculty considered it their educational goal to encourage critical thinking but described the difficulties

Avis, Rupert. 2019. Bi-musical curricula and "abyssal thinking": The case of KM Music Conservatory, India. Action, Criticism, and Theory for Music Education 18 (3): 26-55. https://doi.org/ 10.22176/act18.3.26 
of developing it given entrenched ideas students held about the student-teacher relationship. Alex explained:

It's hard to get critical feedback from students ... Here in India there is a big wall between you and your teacher. It does not come naturally for people to critique their teachers.... A lot of students use regurgitation to generate ideas. They don't challenge or think independently. In composition workshops I ask questions and am greeted by silence. Students are afraid to say something [that's] not correct. Schools here don't teach critical thinking.

Similarly, Joseph stated: "It was difficult in that I found it was not always easy to promote speculative thinking. It's possible they'd been exposed to a type of teaching where the answer is right or wrong." George also described his educational goal as developing students' critical thinking. I observed a lecture George delivered on Jacques Attali's (1977) Noise: The Political Economy of Music. An engaged debate ensued between George and one of the students who challenged the conclusions of the lecture. The content of the debate is less significant than the fact that the debate took place; in contrast, students took a more passive role in the Hindustani classes I observed.

This posed questions for the student-teacher relationship; the gurukul system that Shreya describes is predicated on a guru-shishya relationship in which the teacher is not usually challenged (Ruckert 2004). For example, as Ramnarine notes, in such a system, students are not permitted to embark on a solo career until the teacher gives them permission or thinks that they are ready to do so (Ramnarine 2007). In contrast, the Organisation for Economic Co-operation and Development $^{29}$ (OECD) has described the primary aim of higher education as the development of critical thinking skills, with debate as a primary educational tool.

George describes the issues he felt Shreya faced as a result of a focus on critical thinking: "From her tradition, teacher and guru cannot be questioned. And then she ends up with students who challenge." The combined forces of Western-style critical thinking and Western ideas of student-teacher relationships indicate the tensions that arise from this educational context: teachers in the Western faculty encourage students to debate and challenge ideas, an approach that, according to George, does not sit comfortably with Hindustani classical pedagogy. Related to this, Atkinson (1997) has questioned the appropriateness of teaching Westernstyle critical thinking skills in non-Western contexts, arguing that they embody values and beliefs specific to Western societies. Atkinson notes three issues that are useful to highlight here: first, it is difficult to explain and teach critical thinking; second, critical thinking can be exclusive and reductive, marginalising "alternative tory, India. Action, Criticism, and Theory for Music Education 18 (3): 26-55. https://doi.org/ 10.22176/act18.3.26 
approaches to thought"; and third, and perhaps more crucially, "many cultures endorse modes of thought and education that almost diametrically oppose it" (1997, 72).30 The privileging of critical thinking ahead of alternative ways of thinking raises pertinent issues related to Western cultural hegemony and could serve to invalidate "other" modes of thought and teaching. This generates tensions that go beyond musical content and the acquisition of skills to social dynamics and educational philosophy.

These tensions were brought into relief in debates on the "hybridisation" of the curriculum. I observed a staff meeting where a discussion about hybridisation ensued. Shreya felt students had to gain distinct knowledge of each classical tradition before teaching and learning experiences could be "hybridised" in meaningful ways, whereas Johnny felt that crossovers should be implemented from the start of students' education. Johnny outlined his position:

The music theory needs to be revamped so that you can show the crossovers from the beginning.... We have to redraft the curriculum. I think the way the traditions are shown as relating couldn't be more superficial. They are taught as completely unrelated segregated fields.

The issue here-highlighted by several lecturers-is on whose terms such hybridization takes place, and what implications this might have for pedagogy. Both George and Shreya felt students should be given a firm foundation in both traditions before a fusion of the curriculum could take place. George noted, "The senior faculty do not want to hybridise; there are faculty who do want to hybridise it from its initial stages. We do not think it viable or beneficial for students." Both positions are ultimately marked by ambivalence; in one, the question is how to represent a distinct version of a musical tradition that is not reductive and rigid, and that does not draw on Orientalising discourses to characterise it. In the other, the question is how to develop a hybridised curriculum that does not reduce musical traditions to a meaningless fusion framed by unequal power dynamics. Developing a hybridised curriculum glosses over epistemological and social dimensions of Hindustani classical music education such as the student-teacher relationship, and frame Hindustani education within a curriculum based on UK quality assurance and international concerns.

Avis, Rupert. 2019. Bi-musical curricula and "abyssal thinking": The case of KM Music Conservatory, India. Action, Criticism, and Theory for Music Education 18 (3): 26-55. https://doi.org/ 10.22176/act18.3.26 


\section{Student Experiences}

These tensions played out dramatically in student experiences. The students I interviewed were at various stages in their studies. Four were Foundation (first year students) students, five were Diploma 1 students, and seven were Diploma 2 students. Two respondents were ex-KM students who had subsequently returned as vocal teachers. One had pursued an undergraduate degree at Middlesex University, whilst the other had completed a Diploma course at KM and gone straight into teaching. Three of the students had extensive backgrounds in Carnatic classical music, five had backgrounds in Hindustani classical music, two had a background in both traditions, and three had a background in Western art music. Five had undergraduate degrees from Indian universities in subjects other than music, and one had an undergraduate degree from a university outside India. Student ages ranged from late teens to early thirties. All participants were from an economically privileged background and part of an increasingly affluent, metropolitan middle class.

Many of the students understood or conceptualised their experience of Western art music in relation to Hindustani classical music (and vice versa), drawing on well-established and problematic tropes. Harsh, an 18-year old Diploma 1 student, had grown up in Mumbai learning Hindustani classical music and popular music. He conceptualised Western art music as structured and important in developing the foundational skills required of the "modern" musician:

There are structures behind writing it, there are structures behind performing it.... It's important for a musician to develop that discipline and understand structures. The structures that are followed ... bring the musicians onto the same page.... I'm interested in learning more about harmony [and to] read and write music-it fascinates me. Hindustani is just improvisation, but I want to be able to understand the complexity that music can bring.

"Critical engagement" and understanding are mobilised as signifiers of Western education and its suitability for a "modern" and "globally interconnected" world. Pavi, an ex-student and vocal teacher at KM, also described the aural and theoretical knowledge fostered through Western art music education and the accessibility of scores and text-based knowledge. He stated:

If studying for a degree, it should be Western. You get vocal ability skills from that education. Also, I can go like x-ray vision when I listen to any piece; I can understand it. Counterpoint and the theoretical stuff, sight-reading-every musician should have those skills. It is universal-a person from US will understand you and you will understand him.

Avis, Rupert. 2019. Bi-musical curricula and "abyssal thinking": The case of KM Music Conservatory, India. Action, Criticism, and Theory for Music Education 18 (3): 26-55. https://doi.org/ 10.22176/act18.3.26 
Other students also described the importance of Western art music as a foundation that would equip them with the skills needed in today's music industries, particularly in India. Hitesh, a Diploma 2 student, felt that learning orchestration and listening to Wagner would be useful for composing film music, illustrating the significance of Western art music education to the Indian film industry. ${ }^{31}$ Similarly, Jishu described Western art music education as developing multifaceted skills such as "music theory, history, analytical techniques-for example Schenkerian analysis-critical thinking and so on" that he viewed as essential for the "modern" musician. Gatek also described the importance of studying orchestration for film scoring, as well as developing dictation skills through sight-singing so, as he described, he could "hear the entire sound in my mind and improve overall musicianship." Students often contrasted their experience of Western art music with that of Hindustani classical music. Vijaya describes the distinction between the aural and written traditions of Hindustani classical and Western art music:

In Hindustani we don't have particular [written] records. Hindustani is mostly without proof [and is] an aural tradition -we have to believe. [In Western art music] we get to see the process, really see it and believe it and then we can look for something else in that.

Vijaya's comments illustrate the tensions generated by the pedagogic methods employed by teachers. Here, Western art music is exclusively associated with textbased knowledge and Hindustani classical music with aural-based and "unverifiable" knowledge.

These tropes were also revealed in the ways that students conceptualised and approached performance. Again, students reaffirmed dominant and problematic conceptualisations of performance in both traditions. For Pavi, experiences of Hindustani and Western classical music performance differed considerably:

Because everything is written prior [in Western art music]. The score is there, less scope to improvise.... Indian classical has more freedom for improvising. Western classical has sheet music asking you to get into that feel; you play what's written on the score, but with Indian classical you create the feel. Stage fear is more with the written score, there are strict instructions.

Such representations of Western art music are as reductive as Orientalist representations of Indian classical music. For example, student responses resonate with the notion that the performance of Western art music serves as the reproduction of composers' meanings, privileging text and scores over per-

Avis, Rupert. 2019. Bi-musical curricula and "abyssal thinking": The case of KM Music Conservatory, India. Action, Criticism, and Theory for Music Education 18 (3): 26-55. https://doi.org/ 10.22176/act18.3.26 
formers and the tradition's aural properties. Nicholas Cook $(2014,2)$ has observed that when approached this way, "Western classical performance as in essence a process of reproducing the composer's meaning, something that can be done well or badly but in which the essential criterion of success is faithfulness to the composer's intentions." Cook continues:

The idea of music as a text reproduced in performance is so deeply embedded in thinking about Western "art" music that, however much we might wish to, we find it hard to conceive the role of performers in musical culture more generously (2).

Such attitudes resonate with Hunter and Broad's (2017) identification of the perpetuation of what they call a "classical music ideology," prevalent amongst UK music students, that privileges the ontological status of composers and works. It also resonates with McPhail's (2013) assertion that Western art music is more often associated with technical and formal theoretical knowledge (16). Again, a dichotomy is presented between the Western and Hindustani traditions in which the written and aural become reified opposites.

According to George, the accessibility of learning materials such as scores, books, and online information along with its "structured" and "goal-oriented" pedagogy led to a preference for Western art music amongst students: "We very often find points where they begin to favour one method or the other and will start to challenge the validity of one tradition." Research for this article showed that it was usually the validity of the Indian tradition that was challenged. Rather than epistemological diversity, bi-musical educational experiences at $\mathrm{KM}$ often undermined the validity of Indian classical teaching. Bhakti, a Diploma 1 student, provides some insight into what lay behind these preferences:

I've experienced all three [Hindustani, Carnatic and Western classical] and find Western classical ... so much more engaging because your sessions with teacher are always one-on-one. It's not like that for Hindustani. With the way Western classical music is taught in general, the hows and whys are explained so much better.

Bhakti had initially come to Chennai to study Carnatic classical music but changed her focus to Western art music after becoming disillusioned with the Carnatic teaching she received:

The guru I had found was unfortunately quite the dictator. Demanded hours and a very specific way of learning and would mock you, and I wasn't learning anything. He demanded that you didn't sing anything else, otherwise he wouldn't teach you.... They expect you to invest so much time with so little 
investment from their side. That's how it's taught in general. That just wasn't working for me. There wasn't a guarantee of pay off ... to at least know you were headed in the right direction.

Drawing on the "goal-oriented" aspects of Western education, Bakhti felt Western art music was better suited to "today's world":

It was how organised [KM] was. It wasn't just endless time with a teacher where you had no fixed goal in sight and it may or may not work out.... Obviously that's just not practical in today's world. I mean, how could you not give yourself a deadline with some cut-off, right?

Bhakti's comments resonated with the association of Western pedagogy with modernity, structure, and its perceived relevance to contemporary, metropolitan India, which has been shaped by economic liberalisation, capitalism, and neoliberalism. She felt Indian classical music education was, on the other hand, unproductive and inferior. Her comments indicated how approaches to education such as the guru-shishya and gurukul can be undermined both within KM and contemporary, metropolitan India.

Indeed, there were instances where the Hindustani faculty were put under pressure by students to adapt teaching practices. A sense of friction between the two traditions was experienced by several students as a result of their bi-musical education. Guarav, a Diploma 2 student, described developing

a hatred towards the Hindustani tradition because I couldn't understand what it was teaching us in the long run, and I really started to like the Western because of how precise it is.... Because in Hindustani they sometimes say things in an indirect way.

This "hatred" derived from a contrast between Guarav's perception of the "rigorous" knowledge of Western education compared with the perceived lack of rigour in Hindustani education that he subsequently deemed inferior. This led some students to suggest adaptations to Hindustani classical music teaching. Jishu, a Diploma 2 student, describes one such incident:

In Hindustani class, after Mam [Shreya] had had the staff meeting [the staff meeting during which the hybridisation of the curriculum was discussed], she asked the class "how do you feel about the teaching process in KM and how can it be improved?" You see, Western classical is very professionally taught, with slides and all; Hindustani is very aural and it's not well documented.

Jishu then went on to describe how the exchange with Shreya played out:

We finally inferred that we need power-point slides.... She impromptu translates stuff from Hindi textbooks, and on the basis of this, everybody writes stuff down,

Avis, Rupert. 2019. Bi-musical curricula and "abyssal thinking": The case of KM Music Conservatory, India. Action, Criticism, and Theory for Music Education 18 (3): 26-55. https://doi.org/ 10.22176/act18.3.26 
but it's a very personal notes thing-our notes won't be the same and won't be consistent. In Western we have fixed slides as well, and also have our own notes. Hindustani it's just our notes.

Jishu's description shows the ways in which student-teacher relationships are being challenged in Hindustani lectures and the pressures on Hindustani teachers to adapt their teaching methods.

\section{Concluding Thoughts}

Rather than creating an unproblematic educational environment, bi-musical education at KM has the potential to perpetuate abyssal thinking. For teachers, tensions exist in the negotiation of musical boundaries, teacher-student relationships, and the aims, objectives and values of music education. Members of both faculties adapt teaching styles to students' diverse experiences as well as institutional context. In particular, Hindustani teachers are under direct or indirect pressure to adapt pedagogic methods. For students, their learning experiences often lead to the privileging of Western art music education and the "invalidation" of Hindustani classical music education. Students often draw on Santos' five logics: rigorous knowledge, progress, social classification, the naturalisation of differences, the dominant scale and the logic of productivity, and absences: ignorant, backward, inferior, local or particular, and unproductive or sterile, to articulate and make sense of their educational experiences. This research has shown that, as Martin Stokes states, "music doesn't simply 'flow' across the gap as some, talking more generally about cultural globalisation and transnationalism, like to imply" (Stokes 2012, 99); there are significant musical, socioeconomic, political, and cultural factors that are brought into relief in experiences of KM's bi-musical curriculum. It is therefore imperative that music is not conceived as simply "flowing across the gap" in ways that gloss over the tensions generated by bi-musical curricula and the diverse issues that it brings into dialogue.

Bi-musical education can play a role in destabilising established and dominant narratives as Haddon and others suggest; however, this should be tempered and enhanced through acknowledgement of the ways in which bi-musical education can perpetuate the discourses it is claimed it challenges, especially when framed by institutional, socioeconomic, and political contexts such as those that surround $\mathrm{KM}$. These problematic issues should be acknowledged as an outcome of bi-musical education. This entails recognition of what Santos terms "abyssal thinking" 
from both without-conditions brought about by colonial legacies, neoliberalism and globalisation, as well as from within-the reductive and Orientalist discourses we draw upon to articulate and make sense of our lived experiences. This need not be considered a negative outcome of bi-musical education. It is through the highly problematic discourses generated by bi-musical education where, in my view, the richest learning is to be found, where we can encourage dialogue and interaction between diverse musical epistemologies that also encompasses negotiation and recognition of the influence of broader socioeconomic and political concerns and discourses, and where we can confront dichotomous thinking, universalism, and essentialising narratives through an acknowledgement of their presence in the ways we articulate and make sense of our own lived experiences.

\section{About the Author}

Rupert Avis has just completed a PhD entitled The significance of Western art music in contemporary, metropolitan India at the University of York, UK. The thesis is an ethnomusicological study of the significance of Western art music in contemporary, metropolitan India. He has qualifications in various bowed-string, plucked-string, and keyboard instruments and is currently learning sarangi, gayan and Carnatic violin. His research interests include music education, performance studies, ethnomusicology, and popular music studies.

\section{Acknowledgements}

The author would like to thank the Co-Editor of ACT, Deborah Bradley, and the Guest Editor for this issue on Decolonization, Guillermo Rosabal-Coto, for their encouragement and comments on previous drafts of this article. Thanks are also extended to the anonymous reviewers for their comments. Finally, thanks are given to the participants who took part in this research.

\section{References}

Attali, Jacques. 1985. Noise: The political economy of music. Manchester: Manchester University Press.

Atkinson, Dwight. 1997. A critical approach to critical thinking in TESOL. TESOL quarterly 31 (1): 71-94.

Avis, Rupert. 2017. The Significance of Western art music in contemporary, metropolitan India. $\mathrm{PhD}$ thesis.

Avis, Rupert. 2019. Bi-musical curricula and "abyssal thinking”: The case of KM Music Conservatory, India. Action, Criticism, and Theory for Music Education 18 (3): 26-55. https://doi.org/ 10.22176/act18.3.26 
Baker, Geoffrey. 2014. El Sistema: Orchestrating Venezuela's youth. New York: Oxford University Press.

Baker, Geoffrey. 2016. Editorial Introduction: El Sistema in critical perspective. Action, Criticism, and Theory for Music Education 15 (1): 10-32.

Bakhle, Janaki. 2005. Two men and music: Nationalism in the making of an Indian classical tradition. Oxford: Oxford University Press.

Beaster-Jones, Jason. 2016. Music Commodities, Markets, and Values: Music as Merchandise. New York: Routledge.

Bohlman, Philip. 2005. Music as representation. Journal of musicological research 24 (3-4): 205-26.

Booth, Gregory. 2007. Musicking the other: Orientalism in the Hindi cinema. In Music and Orientalism in the British Empire, 1780-1940s: Portrayal of the East, edited by Martin Clayton and Bennett Zon, 315-38. Aldershot: Ashgate.

Bradley, Deborah. 2012. Good for what, good for whom?: Decolonizing music education philosophies. Edited by Wayne D. Bowman and Ana Lucía Frega, 40933. The Oxford handbook of philosophy in music education. Oxford: Oxford University Press.

Brosius, Christiane. 2010. India's Middle Class: New Forms of Urban Leisure, Consumption and Prosperity. Delhi: Routledge India.

Cambridge, James, and Jeff Thompson. 2004. Internationalism and globalization as contexts for international education. Compare: A Journal of Comparative and International Education 34 (2): 161-75.

Clayton, Martin. 2007. Musical Renaissance and its margins in England and India, 1814-1914'. Edited by M. Clayton and B. Zon, 71-94. Music and Orientalism in the British Empire, 1780-1940s: Portrayal of the East. Aldershot: Ashgate.

Clayton, Martin, and Bennett Zon 2007. Music and Orientalism in the British Empire, 1780-1940s: Portrayal of the East. Aldershot: Ashgate.

Cook, Nicholas. 2014. Between art and science: Music as performance. Journal of the British Academy 2: 1-25.

Derné, Steve, Meenu Sharma, and Narendra Sethi. 2014. Structural changes rather than the Influence of media: People's encounter with economic liberalization in India. New Delhi: Sage India.

Farrell, Gerry. 1997. Indian music and the West. Oxford: Clarendon Press.

Avis, Rupert. 2019. Bi-musical curricula and "abyssal thinking": The case of KM Music Conservatory, India. Action, Criticism, and Theory for Music Education 18 (3): 26-55. https://doi.org/ 10.22176/act18.3.26 
Fernandes, Leela. 2006. India's new middle class: Democratic politics in an era of economic reform. Minnesota: University of Minnesota Press.

Gilbertson, Amanda. 2014. 'Mugging up' versus 'exposure': international schools and social mobility in Hyderabad, India. Ethnography and Education 9 (2): $210-23$.

Goswami, Marami. 2013. Neo-liberalism and higher education in India. Journal of Research in Humanities and Social Science 1 (3): 32-7.

Guhman, Nalini. 2014. Resonances of the Raj: India in the English musical imagination, 1897-1947. Oxford: Oxford University Press.

Haddon, Elizabeth. 2016. Bi-musicality and dialogical musicality: Influences of Javanese gamelan participation on Western instrumental learning. British Journal of Music Education 33 (2): 219-35.

Hunter, Mary, and Stephen Broad. 2017. Reflection and the classical musician. Musicians in the making: Pathways to creative performance, edited by John Rink, Helena Gaunt, and Aaron Williamon, 253-70. Oxford: Oxford University Press.

Joshi, Sanjay. 2017. India's Middle Class. Oxford Research Encyclopaedia of Asian History. Accessed 1/01/2019. http://oxfordre.com/asianhistory/view/10.1093/acrefore/9780190277727.001.0001/acrefore9780190277727-e-179.

Lowe, John. 1998. International and comparative education. International School Journal 17 (2): 18-21.

McPhail, Graham. 2013. The canon or the kids: Teachers and the recontextualisation of classical and popular music in the secondary school curriculum. $R e$ search Studies in Music Education 35 (1): 7-20.

Mignolo, Walter. 2011. The Darker Side of Western Modernity: Global futures, decolonial options. Durham: Duke University Press.

Mignolo, Walter. 2007. Delinking: The rhetoric of modernity, the logic of coloniality and the grammar of de-coloniality. Cultural Studies 21 (2-3): 449-514.

Morcom, Anna. 2017. The Hindi film orchestra: cinema, sounds and meanings. Global perspectives on orchestras: Collective creativity and social agency, edited by Tina Ramnarine, 209-25. Oxford: Oxford University Press.

Nettl, Bruno. 1985. The Western impact on world music: Change, adaptation, and survival. New York: Schirmer Books.

Avis, Rupert. 2019. Bi-musical curricula and "abyssal thinking": The case of KM Music Conservatory, India. Action, Criticism, and Theory for Music Education 18 (3): 26-55. https://doi.org/ 10.22176/act18.3.26 
Nooshin, Laudan. 2011. Introduction to the special issue: The ethnomusicology of Western art music. Ethnomusicology Forum 20 (3): 285-300.

Paranjape, Makarand. 2018. Debating the 'post' condition in India: Critical vernaculars, unauthorized modernities, post-colonial contentions. London: Routledge.

Potter, John, and Neil Sorrell. 2012. A History of Singing. Cambridge: Cambridge University Press.

Quijano, Anibal. 2000. Coloniality of power and Eurocentrism in Latin America. International Sociology 15 (2): 215-32.

Qureshi, R. 2007. Master musicians of India: Hereditary sarangi players speak. London: Routledge.

Radice, William. 2005. Man of a hundred good intentions: How Rabindranath became Tagore, and longed to be Rabindranath again. Lecture given at SapientiaHungarian University of Transilvania. Miercurea Ciuc 6.

Ramnarine, Tina. 2007. Musical performance in the diaspora: Introduction. Ethnomusicology Forum 16 (1): 1-17.

Rosabal-Coto, Guillermo. 2016. Costa Rica's SINEM: A Perspective from Postcolonial Institutional Ethnography. Action, Criticism and Theory for Music Education 15 (1): 154-87.

Ruckert, George. 2004. Music in North India: Experiencing music, expressing culture. Global Music Series. New York: Oxford University Press.

Said, Edward. 1994. Culture and imperialism. New York: Vintage.

Santos, Boaventura de Sousa. 2007. Beyond abyssal thinking: From global lines to ecologies of knowledges. Review (Fernand Braudel Center) 30 (1): 45-89.

Santos, Boaventura de Sousa. 2012. Public sphere and epistemologies of the South. Africa Development 37 (1): 43-67.

Santos, Boaventura de Sousa. 2018. The end of the cognitive empire: The coming of age of epistemologies of the South. Durham: Duke University Press.

Schofield, Katherine B. 2014. Indian music in the Persian collections: The Javahir al-Musiqat-i Muhammadi. British Library.

Schofield, Katherine B. 2016. Musical transitions to European colonialism in the Eastern Indian Ocean: Final summary report. European Research Council. 
Seth, Sanjay. 2007. Subject lessons: The Western education of colonial India. Durham: Duke University Press.

Shope, Bradley. 2008. The public consumption of Western music in colonial India: From imperialist exclusivity to global receptivity. Journal of South Asian Studies 31 (2): 271-89.

Sivadasan, V. 2015. Neoliberal hegemony in education: Higher education policies in India. International Review of Social Sciences and Humanities 10 (1): 1-7.

Sorrell, Neil. 2007. Issues of pastiche and illusions of authenticity in gamelan-inspired composition. Indonesia and the Malay World 35 (101): 31-48.

Stokes, Martin. 2012. Musicians between the hegemonies: a response. Journal of Levantine Studies 2 (2): 93-104.

Subramanian, Lakshmi. 2006. From the Tanjore court to the Madras music academy: A social history of music in South India. New Delhi: Oxford University Press India.

Taylor, Philip. 2015. Mozart in Madrās: Global learning and Western art music. Musica Docta 5 (1): 113-25.

Taylor, Philip. 2016. Navigating the global turn in Western music history pedagogy. Musica Docta 6 (1): 87-92.

Tuck, Eve, and K. Wayne Yang. 2012. Decolonization is not a metaphor. Decolonization: Indigeneity, Education and Society 1 (1): 1-40.

van der Linden, Bob. 2013. Music and empire in Britain and India: Identity, internationalism, and cross-cultural communication. London: Springer.

Vlaeva, Ivanka. 2015. Modernization of north Indian classical music-The process of creations and reception. Tradition and Modernity in Indian Culture 2 (1).

Weidman, Amanda. J. 2006. Singing the classical, voicing the modern: The postcolonial politics of music in South India. Durham: Duke University Press.

\section{Notes}

${ }^{1}$ See https://www.youtube.com/watch?v=OM-xHiZfltU, for a promotional video of KM that provides a useful snapshot of the ways in which its institutional identity is shaped by a desire to portray a global and international outlook and status whilst simultaneously maintaining local connections and resonances.

${ }^{2}$ Chennai is located in southern India in the state of Tamil Nadu.

Avis, Rupert. 2019. Bi-musical curricula and "abyssal thinking": The case of KM Music Conservatory, India. Action, Criticism, and Theory for Music Education 18 (3): 26-55. https://doi.org/ 10.22176/act18.3.26 
${ }^{3}$ See http://kmmc.in/

4 Chennai is an internationally renowned centre for Carnatic classical music and Bharatanatyam dance; Hindustani classical music is generally associated with north India.

5 KM's fees are almost three times that charged by other Indian higher education institutions, which typically charge between INR 2 lakh (c. £2,000-4,000) (see https://www.topuniversities.com/). Due to a lack of government funding (there are no student loans or bursaries and limited scholarship opportunities), students and their families require significant disposable income to be able to study at KM. Given the average family income in India is estimated at around INR 4-5000 (c. $£ 400$ ) per year, it can be assumed that KM students are part of an increasingly affluent middle-class whose parents are willing and able to finance their music education.

${ }^{6}$ This is not to negate valuable outcomes of bi-musical education such as the transference of musical skills, learning and performing strategies. For example, I am currently writing an article on the potential benefits of exposure to Hindustani conceptualisations of performance for Western art music performers suffering from performance anxiety.

7 Portuguese, Spanish, British, Dutch and French communities resident in India during colonialism.

${ }^{8}$ Anglo-Indian is a term used here to describe those of mixed European and Indian heritage.

${ }^{9}$ See http://www.Muséemusical.in

${ }^{10}$ Trinity recently held a pan-Indian tour promoting Western art music alongside popular music examinations (see https://serenademagazine.com/news/trinityfest-2018/).

${ }^{11}$ There is not enough space to detail India's colonial and postcolonial histories in this article. Briefly, European powers have been in India since the Portuguese first settled in Goa in the 15th century. The British consolidated power in 1857 when India officially became part of the British Empire, and India became an independent nation in 1947.

12 Economic liberalisation was initiated in 1991 with the goal of making the economy more market- and service-oriented, expanding the role of private and foreign investment.

${ }^{13}$ It is important to note that there are continuities between the 'old' and 'new' middle-classes, for example in terms of family and societal values (see Joshi, 2017).

Avis, Rupert. 2019. Bi-musical curricula and "abyssal thinking”: The case of KM Music Conservatory, India. Action, Criticism, and Theory for Music Education 18 (3): 26-55. https://doi.org/ 10.22176/act18.3.26 
${ }^{14}$ Bradley Shope has also argued that accomplishment in Western art music symbolised the conquering and control of a hostile environment that was seen as wild and barbarous, resonating with the 'civilising mission' of colonial ideology (2008: 3).

15 It should be noted that the dissemination of music always reflects a complex set of relations, motives, meanings, and narratives.

${ }^{16}$ Macaulay was a nineteenth century British historian and 'Whig' politician.

${ }_{17}$ This became known as the Bentick Act. Seth (2007) describes the clash between Western educators in India and their students during the $19^{\text {th }}$ century, many of whom were unfamiliar with western pedagogic styles and did not 'develop' in the way Western educators had anticipated, adapting and shaping learning strategies.

18 The intermingling of ideas was not unidirectional and influenced Western art music scenes in Britain (see Clayton and Zon et al. 2007 and Ghuman 2014).

19 Nettl (1995) has explored the impact of Western music throughout the world describing the adaptation, survival and continuity of non-Western musical traditions.

${ }^{20}$ This has had an ongoing influence on Indian classical music leading to a reduction in the amount of time audiences are willing to spend listening to it (see Vlaeva 2015).

${ }^{21}$ The embeddedness of the Western orchestra and associated narratives of modernity within Indian film music has been identified by Morcom (2017).

${ }^{22}$ Gregory Booth (2007) has also explored self-Orientalism in relation to Indian film music.

${ }^{23}$ Also see Farrell (1997) on the ways in which Indian music has been (mis)represented by the West in popular music, and Guhman (2014) for representations of India and Indian music by British composers.

24 This is complicated by the significance of these two traditions for Indian film music (see Booth 2007; Beaster-Jones 2014; Morcom 2017). Morcom (2017), for example, has argued the whilst direct engagement with Western art music declined in the period following independence, it was still propagated indirectly via film music.

25 Also see Qureshi 2007 on hereditary sarangi musicians. In addition, as van der Linden notes, the prevalence of the gharana system exists to this day and produces India's leading musical performers (2013: 13). 
${ }^{26}$ Furthermore, continued technological developments-especially the internetcontinue to influence adaptations of both Indian classical music as well as Western art music.

${ }^{27}$ See https://musicacademymadras.in/

28 This finds resonance today; several educational endeavours aim to develop and adapt Indian classical music education to modern contexts such as the Sangeet4All project that markets itself as the first Indian classical programme for young children and is run by Saskia and Shubhendra Rao (see http://www.sangeet4all.com/).

29 The OECD is an intergovernmental economic organisation with 36 member countries, founded in 1961 to stimulate economic progress and world trade. It is a forum of countries describing themselves as committed to democracy and the market economy (see http://www.oecd.org/about/).

$3^{\circ}$ It should be noted that Atkinson's comments may serve to reify oppositional differences between Western critical thinking and 'non-Western' thinking that de Santos warns of.

Avis, Rupert. 2019. Bi-musical curricula and "abyssal thinking": The case of KM Music Conservatory, India. Action, Criticism, and Theory for Music Education 18 (3): 26-55. https://doi.org/ 10.22176/act18.3.26 